\title{
VARIABLES AS CONTEXTUAL CONSTRAINTS IN TRANSLATING IRONY
}

\author{
O A N A B A B Î I \\ Alexandru Ioan Cuza University of Iași
}

\begin{abstract}
The translator's role and responsibility are high in any act of interlingual communication, and even higher when irony, an indirect and deliberately elusive form of communication, is involved in the translation process. By allowing more than one possible interpretation, irony is inevitably exposed to the risk of being misunderstood. This paper attempts to capture the complexity of translating irony, making use of theoretical frameworks provided by literary studies and translation studies. It analyses if and how the types of irony, the literary genres and the cultural, normative factors, perceived as potential contextual constraints, have an impact on the translator' choices in rendering irony in translation, taking illustrative examples from Jonathan Swift, Oscar Wilde, Aldous Huxley and David Lodge's works.
\end{abstract}

Keywords: contextual constraints, types of irony, strategies for translating irony, literary genres, norms

\section{Introduction}

The complexity of translating irony in literary texts arises from a series of interrelated factors that are both intrinsic and extrinsic to the ironic literary text to be translated. On the one hand, the intrinsic factors that may also be regarded as potential sources of risk when translating irony are the types of irony, the literary genres and culture-related normative factors. On the other hand, the extrinsic risk factors relate to a series of subjective choices made by the translator, i.e. his/her perception of the concept of irony, of what it is and how it could be employed as a literary mode in the text to be translated; the translator's recognition and interpretation of irony within a given context is based on his/her knowledge of irony markers or clues, as well as on his/her ability to reconstruct and render the author's ironic intent in translation. Therefore, the translator's mastery of irony will ensure that $\mathrm{s} /$ he will rise to the many challenges it presents. On the other hand, the translator's failure to follow and recreate one or more of 
the links in the chain above can result in a failed attempt at both interlingual and intercultural communication.

How, then, can the translator be sure that the inferences $s /$ he makes in translating ironic literary texts are the most relevant ones? What are the contextual constraints that determine the degree of difficulty in translating irony? Do the various types of irony call for particular translation strategies? Does the literary genre dictate a particular type of irony or translation strategy? Does the period of time or the culture/ideology in which a literary work was written dictate a more extensive use of irony over other similar indirect phenomena?

This article will attempt to answer the questions above by determining the manner in which the three main variables - types of irony, literary genres and cultural factors - functioning as contextual guidelines, may have an impact on the translators' choices in rendering irony in translation. These contextual constraints will be confronted with examples selected from a parallel corpus of original novels and plays and their translations into Romanian and French that has been compiled for the purpose of this investigation. ${ }^{1}$ Although greater emphasis will be placed on the comparison between the original English texts and their corresponding translations into Romanian, the translations into French will operate as a system of reference whenever the strategies used to translate irony differ between the two languages. Further insight into the methods to which translators resort in translating irony will thus be provided.

\section{Types of Irony and Their Translation}

The point of departure of this study on types of irony considered as (possible) contextual constraints in translation was D. C. Muecke's call for a more systematic survey of types of irony (The Compass of Irony 4). In this study, Muecke recognizes the flaws of existing classifications of irony as being determined by the fact that "some have been named from the effect, others from the medium, others again from the technique, or the function, or the object, or the practitioner, or the tone, or the attitude (4)." Some forty pages later, he found himself forced to conclude that "I do not know of any book or article [...] or of any European or American dictionary or encyclopaedia which presents a classification of irony one could regard as adequate (40)." To this, Norman

\footnotetext{
1 The literary works included in our parallel corpus that have irony as a common denominator belong to different historical periods and incorporate different types of irony. They are: Gulliver's Travels (1726) by Jonathan Swift; An Ideal Husband (1895) and The Importance of Being Earnest (1898) by Oscar Wilde; Point Counter Point (1928) and Brave NewWorld (1932) by Aldous Huxley; Changing Places (1975) and Small World (1984) by David Lodge, together with their translations into Romanian and French.
} 
Knox added that the confusion on the subject "comes from taking a part for a whole, such as verbal irony, dramatic irony, cosmic irony, [which] isolate the field of observation; others, such as tragic irony, satiric irony, philosophical irony, isolate one aspect" ("On the Classification of Ironies" 53). Again, according to Muecke (The Compass 4), the five factors a viable classification of types of irony should respect are: (1) the field of observation; (2) the degree to which the real meaning is concealed; (3) the relationship between author, audience and victim; (4) the philosophical-emotional aspect; and finally (5) the kind of relationship between the ironist and the irony.

Knox's conditions of a good classification of irony matched Muecke's: (1) the field of observation in which irony is noticed, (2) the degree of conflict between appearance and reality, ranging from the slightest of differences to diametrical opposites, (3) an inherently dramatic structure containing three roles - victim, audience, author and, finally, (4) the philosophical-emotional aspect ("On the Classification" 53). Muecke's classification, however, contains one final factor, namely the kind of relationship between the ironist and the irony, which Knox discourages, due to the fact that, according to him, the ironist never fully withdraws from any type of irony that he employs: "it is true that he sometimes raises his voice, as in parody, but so does the dramatized ironist when he cuts away all flesh to reveal the bone of an ironic event" (Knox 55). Knox, therefore, considers the classification of irony into impersonal, self-disparaging, ingénu and dramatized as irrelevant. His taxonomy, however, makes no allowance, for example, for Socratic irony, the first type of irony from which all the others emerge, or echoic and standard irony. If, in 1972, when Norman Knox wrote his article on the classifications of irony, dichotomies such as intentionalunintentional or echoic-standard irony had not yet been taken into consideration, he surely ought not to have overlooked Socratic irony, all the more so as eleven years before he had published "The Word Irony and Its Context" in which he had constantly referred to Socrates and his method. The problem lies perhaps in the fact that he has subclassified Socratic irony as a form of self-depreciation, whereas Muecke regards it as a form of impersonal irony, one of the four modes of irony he devised, besides the self-disparaging one, which would be the equivalent of Knox's self-depreciation.

Muecke distinguishes between impersonal - blaming in order to praise irony, and self-disparaging irony as two different modes of irony classified according to the kind of relationship between the ironist and the irony. The method practiced by Socrates is, indeed, depreciating but only when considered in relation to the victim. As stated by Quintilian: Socrates "assumed the role of an ignorant man lost in wonder at the wisdom of others" (Quintilian cited in Knox, The Word Irony and its Context 100). If we agree with Knox and Muecke to subclassify Socratic irony as a form of self-disparagement or depreciation, then, I believe, we narrow down the scope of Socratic irony which succeeded in 
doing much more. The irony of Socrates became a method, and his method a way of life. Moreover, echoic irony should not be overlooked or left out of a classification of irony as it is among the easiest recognisable types of irony by the attentive reader, and therefore a safety method for the author who wants his irony to be grasped. All the more so as it has been discovered after an extensive inferential approach to pragmatics and explored in Sperber and Wilson's cognitive psychology (1981).

From the point of view of the translator, it becomes evident that Knox's factors for establishing a viable classification of irony are not entirely adequate. When it comes to translating, the philosophical-emotional aspect of irony is an unnecessary evil, hardly the first thing on the translator's mind when it comes to rendering the ironic message as faithfully as possible into the target language. Thus, even though Knox rejects Muecke's classification of irony according to the relationship between the ironist and the irony, and suggests replacing it by that between the victim, audience and author, I believe that Muecke's classification is more useful for translators, because it gives a name, and consequently draws attention to the textual and stylistic methods in which writers used language in order to activate the irony.

Among the many types of irony classified according to various perspectives (Anolli 2000; Littmann and Mey 1991; Worcester cited in Knox 1961; Abrams 2005; Colebrook 2004; Booth 1972; Sperber and Wilson 1981, to name but a few), the only types of irony which, in my opinion, the translator ought to be familiar with in view of translation, while being as faithful as possible to Knox's factors of a viable classification, are:

\section{Field of observation}

1. Verbal

1.1. double entendre

1.2. verbal irony in which words come into conflict with some element of the world / violation of common knowledge / known error proclaimed - verbal factual irony

2. Situational

2.1. dramatic

2.2. tragic

2.3. irony of fate

II. Degree of conflict between appearance and reality

1. Overt

2. Covert

3. Stable

4. Unstable 
III. Relationship between the ironist and the irony

1. Impersonal

\subsection{Socratic}

1.2. praise-by-blame

1.3. irony of manner

1.4. rhetorical

1.5. innuendo and insinuation

1.6. irony by analogy

1.7. pretended omission of censure

1.8. pretended attack upon the victim's opponent

1.9. internal contradiction

1.10. fallacious reasoning

1.11. understatement

1.12. overstatement

1.13. irony displaced

1.14. echoic

1.15. stylistically signalled irony

2. Self-disparaging

3. Ingénu

4. Dramatized

IV. Philosophical, literary, and intellectual movements

1. Romantic

2. Post-structuralist

3. Postmodernist

In anticipation, verbal irony is perhaps the type of irony that causes most difficulties in translation due to the fact that irony is based on language and word use, i.e. on wordplay and multiple meanings of words in double entendre irony; this might cause translation problems in case there are differences at word level between the source and target languages. The difference between double entendre and verbal irony, in which words come into conflict with some element of the world (in Wayne C. Booth's words "known error proclaimed" - $A$ Rhetoric of Irony 57) is important in order to determine whether or not all verbal irony causes difficulties in translation. On the other hand, I will consider situational irony in view of translation as any case of irony that is nonverbal. I do not believe that Knox's sub-classification of situational irony into ideas, characters, situations and events is relevant for translation. Moreover, even though I have included dramatic irony and irony of fate as subcategories of situational irony, this does not mean that situational irony can only be dramatic 
or fate-determined. Situational irony is inclusive of, but not limited to, these two types of irony.

Furthermore, the distinction between overt and covert irony is important when analysing a text for translation, given that overt irony is local, therefore possibly based on deliberately unconcealed linguistic polysemy, near-synonymy, etc. Thus, it can be more easily observed and translated. Covert irony, instead, is much better disguised, therefore more problematic to interpret and translate, and has a wider scope. I have included Wayne C. Booth's classification of stable and unstable irony (A Rhetoric 1-240) in this category as well, because in this classification irony is analysed according to the degree of conflict between appearance and reality, and it completes Muecke's taxonomy in a significant manner. Stable irony is also meant to be easily understood by readers but, unlike overt irony, it is not pointed out directly by the writer.

I have further included Socratic irony as a subcategory of impersonal irony due to the fact that they both send across the ironist's message, while at the same time his/her position remains unrevealed. By not saying what he/she means, the ironist remains private. This is the case of absence or negativity that Søren Kierkegaard has discussed in On the Concept of Irony with Constant Reference to Socrates (qtd. in Colebrook, Irony 28).Moreover, I have regarded blame-by-praise irony, a term which has been used by many scholars to refer to the method practiced by Socrates, only as a subclassification of Socratic irony, the latter being inclusive of, but not limited to, this type of irony. The other forms of impersonal irony, i.e. pretended agreement with / defense of the victim, pretended error or ignorance, innuendo and insinuation, self-disparaging, internal contradiction, fallacious reasoning, understatement, etc. are relevant because they designate the strategy used by the writer in order to achieve the irony. I have, however, added irony of manner and echoic irony to Muecke's subclassification, the latter being a term coined by Sperber and Wilson ("Irony and the Use-Mention Distinction" 306), as a method that triggers irony through methodical repetition. Moreover, I have completed the classification of types of irony with Romantic, post-structuralist and postmodernist ironies, drawing on Claire Colebrook's Irony (47-98), and including them in a category that integrates irony with philosophical, literary, and intellectual movements.

In what follows, I will exemplify the main types of irony comprised in my classification with ironic excerpts, in the original and in translation, in order to attempt to find out which of these main types of irony are indeed problematic for translators, what are the specific problems which they pose, and, finally, which translation strategies are used for each of these various types of irony.

For this purpose, I will resort to the only existing classification to date of strategies for translating irony, as it has been drawn up by Marta Mateo in "The Translation of Irony" (175-177), namely: 
(1) ST irony becomes TT irony with literal translation;

(2) ST irony becomes TT irony with "equivalent effect" translation;

(3) ST irony becomes TT irony by means of different effects from those used in ST (including the replacement of paralinguistic elements by other ironic cues);

(4) ST irony is enhanced in TT with some word / expression;

(5) ST ironic innuendo becomes more restricted and explicit in TT;

(6) ST irony becomes TT sarcasm;

(7) The hidden meaning of ST irony comes to the surface in TT. No irony in TT;

(8) ST ironic ambiguity has only one of the two meanings translated in TT. There is no double entendre or ambiguity in TT therefore;

(9) ST irony is replaced by a "synonym" in TT with no two possible interpretations;

(10) ST irony is explained in footnote in TT;

(11) ST irony has literal translation with no irony in TT;

(12) Ironic ST is completely deleted in TT;

(13) No irony in ST becomes irony in TT.

These thirteen strategies devised by the Spanish translation scholar are highly valuable for the purposes of this article due to the fact that they encourage a more descriptive research of the methods adopted by translators when rendering irony in translation.

\section{Type of irony according to the field of observation ${ }^{2}$}

A first classification of irony devised by Muecke is based on the field of observation (The Compass 53):

1. Verbal irony is defined as "a statement in which the meaning that a speaker implies differs sharply from the meaning that is ostensibly expressed" (Abrams, A Glossary 142):

Source text 1: You can hardly imagine that I and Lord Bracknell would dream of allowing our only daughter - a girl brought up with the utmost care - to marry into a cloak-room, and form an alliance with a parcel? (Wilde, The Importance of Being Earnest 311).

Target text 1: Vous n'imaginez sans doute pas que Lord Bracknell et moi consentirions à ce que notre fille unique, une jeune fille élevée avec le plus

\footnotetext{
${ }^{2}$ Intratextual bolds signal ironic instances and are all mine, unless stated otherwise.
} 
grand soin, se marie dans une consigne et forme une alliance avec uncolis !(Wilde, L'Importance d'être Constant 103).

The French translator made the same choice as the Romanian one (see Mateo's 11th strategy for translating irony listed above), and translated the meaning of "marrying into" literally, i.e. "marrying inside (a clock-room)." The literal translation has consequently lost the ironic intent of the original text.

Source text 2: GWENDOLEN: [severely] Had you never a brother of any kind?

JACK: [pleasantly] Never. Not even of any kind (Wilde, The Importance 340).

Target text 2: GWENDOLEN (severă): Nu ai avut niciodată, nici un fel de frate?

JACK (amabil): Niciodată. De nici un fel (Wilde, Ce înseamnă să fii onest 304).

The verbal irony in this excerpt was translated into Romanian by means of “equivalent effect" translation, Mateo's 2nd strategy. Literal translation was impossible in this case due to linguistic asymmetries. The Romanian language uses double negation, which is considered to be a mistake in English.

Source text 3: I ventured to offer to the learned among them a conjecture of my own, that Laputa was QUASI LAP OUTED; LAP, signifying properly, the dancing of the sunbeams in the sea, and OUTED, a wing; which, however, I shall not obtrude, but submit to the judicious reader (Swift, Gulliver's Travels 175).

Target text 3: Am îndrăznit să le împărtăşesc învăţaţilor o părere a mea şi anume că Laputa ar veni aproximativ de la Lap outed, lap însemnînd, propriu-zis, jocul razelor de soare în apele mării, iar outed - aripă, părere pe care totuşi nu vreau s-o impun neapărat, ci doar s-o spun cititorului judicios (Swift, Călătoriile lui Gulliver 188).

This example from Gulliver's Travels illustrates verbal irony at its best. It is based on the etymology of the name Laputa (the true one being the Spanish "whore"), which Gulliver assumes to infer due to his remarkable language skills. He is, however, wrong in his views, and herein lies the irony, translated literally into Romanian. Being a Spanish word in the original English text, the Romanian translator did not consider it necessary to explicitate it further in his translation a thing which leads to 'undertranslation' - its true etymology being submitted "to the judicious reader." 
2. Situational irony reveals an incongruity between the expected and the actual outcome of events:

Source text: [...] the members should raffle for employments, [...] giving security that he would vote for the court, whether he won or no; after which the losers had in their turn the liberty of raffling upon the next vacancy. Thus hope and expectation would be kept alive, none would complain of broken promises, but impute their disappointments wholly to fortune [...] (Swift, Gulliver's Travels 209).

Target text: [...] marile dregătorii să fie cîștigate la loterie, [...] fiecare senator trebuind să depună în prealabil jurămînt și garanție că va vota pentru curte, fie ca va câștiga sau nu; cei care pierdeau aveau libertatea să joace la loterie pentru următorul post vacant. În felul acesta speranța și probabilitatea erau veșnic vii, nimeni nu putea să se plîngă de făgăduieli ce nu fusereră ținute, ci punea dezamăgirile numai pe seama sorții [...] (Swift, Călătoriile lui Gulliver 222).

The manner in which employments could be obtained, by raffling, blaming or thanking fortune for one's career path is an example of situational irony which was translated into Romanian by means of Mateo's 'equivalent effect' ("The Translation of Irony" 175-177).

\section{Type of irony according to the degree of conflict between appearance and reality}

Muecke has construed a second classification of irony "according to the degree to which the real meaning is concealed" (The Compass 53).

1. In overt irony "the victim or the reader or both are meant to see the ironist's real meaning at once" (Knox, "On the Classification" 55).

Source text: LADY MARKBY: [...] But modern women understand everything, I am told.

MRS CHEVELEY: Except their husbands. That is the one thing the modern woman never understands.

LADY MARKBY: And a very good thing too, dear, I dare say. It might break up many a happy home if they did (Wilde, An Ideal Husband 224).

Target text: LADY MARKBY: [...] Dar, după cîte am auzit, femeile moderne înțeleg totul.

DOAMNA CHEVELEY: Totul, în afară de soți. Ăsta este singurul lucru pe care femeia modernă nu-l înțelege niciodată.

LADY MARKBY: Asta e foarte bine, dragă, după părerea mea. Dacă nevestele și-ar înțelege soții, s-ar destrăma multe căsnicii fericite (Wilde, Un sot ideal 207). 
Both literal and 'equivalent effect' translation (Mateo 175-177), the latter of which reproduces the effect of the source text in the target text, were used to render this excerpt into Romanian. The paradox was also successfully rendered in translation.

2. Covert irony "continually shifts [the writer's] ground precisely so as to keep one step ahead of the reader who thinks he has caught up with him" (Muecke, The Compass 59).

Source text 1: Brave New World (Huxley 2007)

Target text 1.1: Minunata lume nouă (Huxley 2011)

Target text 1.2: Le meilleur des mondes (Huxley 1977)

Brave New World is the title of a novel written by Aldous Huxley deriving from Miranda's speech in The Tempest by William Shakespeare. It was translated with equivalent effect into Romanian, the translator opting to describe this apparently utopian world by the adjective "minunant" (wonderful), instead of "brave." The French version, however, was translated as Le meilleur des mondes (the best of all worlds) an "equivalent effect" translation solution that alludes to an expression used by Gottfried Leibniz and is satirised by Voltaire in Candide.

Source text 2: 'They give you five minutes of a movie for free, to get you interested,' Morris explained. 'Then if you want to watch the whole thing, you call and have them pipe it to your room and charge it.' 'Everything on tap,' said Persse shaking his head. Oh brave new world! (Lodge, Small World 328)

Target text 2.1: Îți dau gratuit câte cinci minute din mai multe filme, ca să te atragă, îi explică Morris. Pe urmă, dacă vrei să vezi vreunul în întregime, dai telefon să ți-1 trimită prin cablu în cameră și să ți-l pună la nota de plată.

- Totul la comandă, zise Persse clătinînd din cap. $\mathbf{O}$, minunată lume nouă! ${ }^{1}$ (Lodge, Ce mică-i lumea! 355)

Translator' s footonote:

${ }^{1}$ Citat din Furtuna de William Shakespeare, care dă și titlul unui cunoscut roman de Aldous Huxley (Lodge, Ce mică-i lumea! 355). [Quote from The Tempest by William Shakespeare, which is also the title of a famous novel by Aldous Huxley.]

Target text 2.2: On vous passé gratuitement cinq minutes de film pour vous appâter, expliqua Morris. Eu si vous souhaitez voir tout le film, vous téléphonez pour leur demander qu'on vous le passe dans votre chambre et qu'on ajoute ça sur votre note. 
des mondes

-On vous livre tout à domicile, dit Persse en secouant la tête. Oh, le meilleur

(Lodge, Un tout petit monde! 504)

The brave new world is also present in Small World by David Lodge, and explained in a footnote by the Romanian translator [Mateo's 10th strategy, ST irony is explained in footnote in TT, (175-177)] in order to draw attention to the author's allusion to Huxley's novel; it is rendered through the "equivalent effect strategy" in French.

3. In the case of stable irony "the meanings are hidden, but when they are discovered by the proper reader they are firm as a rock" (Booth 235).

Source text: Then I went to America where they have discovered that some men have arms shorter than average(in Britain for some reason you are only allowed to have arms that are longer than average) and bought a dozen shirts at Brooks Brothers with 32 inches sleeves (Lodge, Therapy 20).

Target text: Pe urmă am fost în America, unde s-a descoperit că unii oameni au brațele mai scurte decît media (nu știu de ce, dar în Anglia ți se permite să ai doar brațe mai lungi decît media) și am cumpărat de la Brooks Brothers douăsprezece cămăși cu mîneci măsura 32 (Lodge, Terapia 31).

Neither have the Americans discovered that it is possible to have shorter hands than the average, nor did the British prohibit having short hands in Britain. The irony was successfully preserved in the Romanian text via literal translation.

4. When using unstable irony, the author "refuses to declare himself, however subtly, for any stable proposition, even the opposite of whatever position his irony vigorously denies" (Booth 240).

Source text: Philip: 'I mean, mentally you brace yourself for the ending of a novel. As you're reading, you're aware of the fact that there's only a page or two left in the book, and you get ready to close it. But with a film, there's no way of telling, especially nowadays, when films are much loosely structured, much more ambivalent [...].'Philip shrugs. The camera stops, freezing him in mid-gesture. THE END (Lodge, Small World 218).

Target text: Philip: Vreau să spun că te fortifici, mental, pentru clipa când romanul se va termina. Citind, devii conștient de faptul că nu ți-au mai rămas din carte decât o pagină sau două; aşadar, te pregătești să o închizi. La unfilm, însă, n-ai cum să prevezi sfârșitul, mai ales astăzi, când filmele au o structură mult mai dezlânată, mult mai ambivalentă, decât înainte [...]. Philip ridică din umeri. Filmul se termină cu un stop-cadru care îl îngheață în acest gest. SFÂRȘIT (Lodge, Ce mică-i lumea! 267). 
Through a kind of mise-en-abime device, the discussion about being able to predict the endings of novels in Changing Places by David Lodge ends rather abruptly, with the characters freezing in mid-gesture, and the novel ending unexpectedly. Both literal and 'equivalent effect' translation were used to render the irony into Romanian.

\section{Type of irony according to the relationship between the ironist and the irony}

D.C. Muecke third classification of irony is based on the relationship between author, audience and victim (The Compass 53).

1. Impersonal irony isone of the four modes of irony alongside with self-disparaging, ingénu

and dramatized irony. It sends across the message of the ironist, while at the same time remaining ignorant of his presence as a person.

Source text: LORD GORING: During the season, father, I only talk seriously on the first Tuesday in every month, from four to seven.

LORD CAVERSHAM: Well, make it Thursday, sir, make it Thursday.

LORD GORING: But it is after seven, father, and my doctor says I must not have any serious conversation after seven. It makes me talk in my sleep.

LORD CAVERSHAM: Talk in your sleep, sir? What does that matter? You are not married (Wilde, An Ideal Husband 235).

Target text: LORD GORING: În timpul sezonului monden, tată, nu întrețin conversații serioase decît în prima marți a fiecărei luni, între patru și șapte. LORD CAVERSHAM: Ei, domnule, să presupunem că azi e marți. Să zicem că e marți.

LORD GORING: Bine, tată, dar e trecut de șapte, și doctoral mi-a zis că nam voie să duc discuții serioase după ora șapte, pentru că astfel vorbesc prin somn.

LORD CAVERSHAM: Vorbești prin somn, domnule? Și ce importanță are ? Doar nu ești însurat (Wilde, Un soţ ideal 219).

The schedule of serious conversations which Lord Goring is capable of carrying out and the fact that talking in one's sleep is dangerous if one is married has been (successfully) translated into Romanian using three of Marta Mateo's strategies for translating irony: literal, 'equivalent effect' translation and enhancement of irony in TT, through the addition of "doar" in "Doar nu ești însurat" [it is not like you are married]. 
2. Self-disparaging irony brings the ironic author in the centre of attention "in the character of an ignorant, credulous, earnest or over-enthusiastic person" who functions as the "guide to the ironist's real opinion" (Muecke, The Compass 87):

Source text: If there's such a thing as reincarnation, I wouldn't mind coming back as a squirrel. They must have knee-joints like tempered steel (Lodge,Therapy 3).

Target text: Dacă există reîncarnare, zău că mi-ar plăceasă mă întrupez în veveriţă. Cred că au articulaţiile rotuliene din oțel călit (Lodge, Terapia 11).

The addition of the interjection "zău" [I'm sure / why / I say!] by the Romanian translator produces a stronger ironic effect than its original counterpart in English, "I wouldn't mind," which has more direct equivalents in Romanian than the version chosen by the translator (for example, nu m-ar deranja). ST irony is thus enhanced in TT.

3. Whenresorting to ingénu irony, the ironist uses a simpleton, or else an "ingénu who nonetheless sees what the clever ones are blind to, or cannot be brought to comprehend their sophistries" (Muecke 63):

Source text: The beast and I were brought close together, and by our countenances diligently compared both by master and servant, who thereupon repeated several times the word YAHOO. My horror and astonishment are not to be described, when I observed in this abominable animal, a perfect human figure (Swift, Gulliver's Travels 253).

Target text: Animalul fu aşezat alături de mine, iar stăpînul şi servitorul, comparînd cu grijă chipurile noastre, repetară de mai multe ori cuvintul yahoo. $\mathrm{Nu}$ pot zugrăvi scîrba şi uimireace $\mathrm{m}$-a cuprins cînd am băgat de seamă că acest animal hidos avea o înfăţişare întru totul asemenea oamenilor (Swift, Călătoriile lui Gulliver 272).

In the translation of Gulliver's first impression of the Yahoos into Romanian, the ST ironic innuendo becomes more explicit in TT, as in the Romanian language the noun "bestii" [beasts] has a much more powerful ironic impact than "animal" when the reader realises that the Yahoos were, in fact, people. 'Equivalent effect' translation was the other strategy used to translate the irony in this passage. 
4. When it comes to dramatized irony, the ironist has withdrawn to the point that "it is no more [...] than the presentation in drama or fiction of such ironic situations or events as we may find in life." (Muecke 63):

Source text: GWENDOLEN: [...] my ideal has always been to love someone of the name of Ernest.

JACK: But you don't really mean to say that you couldn't love me if my name wasn't Ernest?

GWENDOLEN: But your name is Ernest.

JACK: Yes, I know it is. But supposing it was something else? [...] I think,

Jack, for instance, a charming name.

GWENDOLEN: Jack? ... No, [...] I have known several Jacks, and they all, without exception, were more than usually plain. Besides, Jack is a notorious domesticity for John! And I pity any woman who is married to a man named John (Wilde, The Importance 306-307).

Target text: GWENDOLEN: [...] idealul meu dintotdeauna a fost să iubesc pe cineva cu numele Onest.

JACK: Dar spune-mi, crezi într-adevăr că nu m-ai putea iubi, dacă nu m-aş numi Onest?

GWENDOLEN: Dar numele tău este Onest!

JACK: Da, știu! Dar să zicem că m-aș numi altfel. [...] Jack, de exemplu, găsesc că e un nume fermecător.

GWENDOLEN: Jack? Nu, [...] am cunoscut cîțiva Jack și toți, fără excepție, erau mai mult decît banali. Și apoi, Jack nu-i decît un diminutiv extrem de comun pentru John! Compătimesc orice femeie căsătorită cu un John (Wilde, Ce înseamnă să fii onest 270).

The name Ernest, on which the ironic pun is based in the original title, was replaced by a (partial and phonological kind of) synonym in translation, "Onest" (Br. adj. "honest"), which, however, has never been used as a proper name in Romanian. Still, the translated play was entitled Ceînseamnă să fii onest ["What It Means to Be Honest"], in order to preserve, in Romanian as well, Wilde's ironic intention.

\section{Type of irony according to philosophical, literary and intellectual movements}

This category, which I have added to Muecke's classification, integrates irony with philosophical, literary, and intellectual movements.

1. Romantic irony designates a mode of literary writing "in which the author builds up the illusion of representing reality, only to shatter the illusion by revealing that the author, as artist, is the creator and arbitrary manipulator of the characters and their actions" (Abrams, A Glossary 144). 
Source text: 'But I like the inconveniences.'

'We don't,' said the controller. 'We prefer to do things comfortably.'

'But I don't want comfort. I want God, I want poetry, I want real danger, I want freedom, I want goodness. I want sin.'

'In fact,' said Mustafa Mond, 'you're claiming the right to be unhappy.'

'All right them," said the Savage defiantly, 'I'm claiming the right to be unhappy' (Huxley, Brave New World 211-212).

Target text: - Dar mie îmi plac inconvenientele.

- Nouă nu. Noi preferăm să facem totul într-un mod confortabil.

Eu unul nu vreau confort. Îl vreau pe Dumnezeu, vreau poezie, vreau primejdie adevărată, vreau libertate, vreau bunătate. Vreau păcatul. spuse Mustafa Mond.

De fapt, dumneata pretinzi dreptul de a fi nefericit, îi

Mă rog, fie și aşa! Îl sfidă Sălbaticul. Cer dreptul la nefericire (Huxley, Minunata lume nouă 255).

Irony is based here on the apparent paradox that the Savage is claiming his right "to be unhappy" in order to live his life outside of Ford's dystopian world. The irony was translated literally into Romanian.

2. Post-structuralist irony: Claire Colebrook (Irony 94) has drawn on Jacques Derrida's deconstruction to define post-structuralist irony as any text that "has a force to disrupt what we take to be stable and decided. All meaning is potentially ironic" (105). Any text requires doing and undoing and irony is a manner to achieve that.

Source text: I thought deconstructionists didn't believe in the individual. They didn't. But death is the one concept you can't deconstruct. Work back from there and you end up with the old idea of an autonomous self. I can die, therefore I am. I realized that when those radicals threatened to deconstruct me (Lodge, Small World 328).

Target text: - Credeam că deconstructiviștii nu cred în individ.

- Păi nici nu cred. Moartea, însă, este singurul concept care nu poate fi supus deconstrucției. Ia-o îndărăt dinspre ea și o să ajungi la vechea idee a eului autonom. Pot muri, deci exist ${ }^{1}$. Mi-am dat seama de acest adevăr atunci când broscarii ăia radicali m-au amenințat că or să treacă la deconstrucția persoanei mele (Lodge, Ce mică-i lumea! 355).

Translator's footnote: 
${ }^{1}$ Parafrază ironică a celebrei maxime a filosofului raționalist francez René Descartes (1596-1650) cogito ergo sum "gândesc, deci exist." [Ironic paraphrase of the famous proposition coined by the French Rationalist and philosopher René Descartes (1596-1650) cogito ergo sum, "I think, therefore I am"].

The existential irony in this excerpt from Small World by David Lodge, based on the allusion to René Descartes' philosophical proposition "I think, therefore I am," was explained in a footnote in the Romanian translation (Mateo's 10th strategy, ST irony is explained in footnote in TT).

According to this sample of texts selected from my corpus, it can be stated that the translation strategies used by professional translators in order to render each of the main types of irony in translation, sorted from the most to the least common, are the following: (2) ST irony becomes TT irony with "equivalent effect" translation; (1) ST irony becomes TT irony with literal translation; (4) ST irony is enhanced in TT with some word / expression; (10) ST irony is explained in footnote in TT; (5) ST ironic innuendo becomes more restricted and explicit in TT; (9) ST irony is replaced by a "synonym" in TT with no two possible interpretations; and finally (11) ST irony has literal translation with no irony in TT.

Among the main types of irony exemplified in this section, verbal irony appears to be the most problematic for translators, based on the fact that, out of the three selected texts, one was translated literally, with no consideration for the ironic intent conveyed in the original. I refer here to the first example of verbal irony from The Importance of Being Earnest by Oscar Wilde. Whereas literal translation could not have been employed in order to render this particular instance of verbal irony into Romanian or French, for reasons of linguistic asymmetry, other strategies, such as equivalent effect translation, could have been resorted to. The conclusion that could be drawn is that, by translating the text literally, the translator missed the verbal irony in the original.

Moreover, most of the problems which the various types of irony pose in translation are culture-specific. Covert irony which, by definition, is concealed was explained in the translators' explanatory footnotes. Their function was precisely to draw attention to those cultural references which the target readers might have otherwise missed. Similarly, the so-called "post-structuralist irony" was also explained in a translator's footnote, in order to reveal an additional layer of meaning to the Romanian readers, without interfering with the text. Dramatic irony raised translation problems only insofar as it was based on cultural habits, present only in the British culture, which could not be faithfully rendered in translation. The compromise made by the translator in this case 
could ensure an equivalent effect in translation only if the Romanian readers accepted the solution found by the translator as a textual reality, despite its cultural oddity (e.g. The Importance of Being Earnest - Ce inseamnă să fii onest). The other translation difficulties were caused by differences between the languages involved in the translation process, which were generally overcome by means of equivalent effect translation. The involvement of culture and of literary genre in the translation of literary irony will be discussed in greater detail in what follows.

\section{Literary Genre as a "Contextual Constraint" in Translating Irony}

In The Translator as Communicator, Hatim and Mason distinguish between three different semiotic categories in which irony can be found: text, genre and discourse. Genre has been defined as "conventional forms of texts associated with particular types of social occasion," or "ways in which linguistic conventions cater for or respond for particular social occasions" (qtd. in Angeles Ruiz Moneva, "Searching for Some Relevance Answers" 220). There are many types of irony in literature that can be found in most, if not all, literary genres, which is not to say that the issue has been settled.

In answer to the question of whether or not the literary genre dictates the use of a particular type of irony, verbal irony on the part of the narrator, for example, is said to be characteristic especially of 18th and 19th century novels, when narrators assisted the readers in the interpretation of their novels as if they were on a guided tour. It was after this period that "the art of fiction [began when] the novelist thinks of his story as a matter to be shown, to be so exhibited that it will tell itself" (Muecke, Irony and the Ironic 90).

When it comes to plays, the most characteristic way of setting up the plot is by means of dramatic irony, when at least one character is left outside the playwright's circle of confidence and becomes the victim of his own ignorance. The most striking difference between novels and plays, however, is the scope which they allow for irony to manifest itself. The former genre "permits greater length, hence wider scope and finer details, hence complexity, hence explanation, reflection and deliberation. It removes the need to hold the audience's attention by being on the one hand theatrical and dramatic and on the other hand immediately and easily intelligible" (Irony and the Ironic 93).

In Point Counter Point, for example, Aldous Huxley created a multilayer structured novel in which the focus of the novel is shifted onto the manner in which the characters' stories are told, following the technique of counterpoint in music:

Meditate on Beethoven. The changes of moods, the abrupt transitions.(Majesty alternating with a joke, for example, in the first movement of the B flat major Quarter.Comedy suddenly hinting at prodigious and strategic solemnities in the 
scherzo of the C sharp minor Quartet.) More interestingly still, the modulations, not merely from one key to another but from mood to mood. A theme is stated, then developed, pushed out of shape, imperceptibly deformed, until, though still recognizably the same, it has become quite different" (Huxley, Point Counter Point 384).

The plots run in parallel, independent of one another, but intersect in just the right places to be able to draw substance and to call the novel a whole. By breaking away from the conventional structure of the novel, which describes characters and/or sequential events, the novel of ideas is architectonically ironic and deliberately artificial:

The chief defect of the novel of ideas is that you must write about people who have ideas to express - which excludes all but about .01 per cent of the human race. Hence the real, the congenital novelists don't write such books. But then I never pretended to be a congenital novelist. The great defect of the novel of ideas is that it's a made-up affair (Huxley. Point Counter Point386).

This is a typical case of echoic irony, in which words are repeated ("defect of the novel of ideas") in order to draw attention to ironic construction by means of emphasis. Whenever irony is embedded in the very structure of the novel, therefore, as a global strategy, there are also plenty of cases of local irony, expressed in a more condensed manner, but nonetheless carefully framed within the novel as a whole, as an irony within another irony:

Perhaps when I was at Vienne last year, I actually consumed a piece of Mozart's substance. It might have been in a Wiener Schnitzel, or a sausage, or even a glass of beer (Huxley, Point Counter Point 38).

The topic in this last example is the same, the musicalization of fiction, or rather music as a formal and thematic literary construct, but the approach is different. By being local, irony is meant to be perceived at once and to achieve instant effect. This kind of irony, framed within the global ironic structure of the novel, apart from adding depth to the communication, in terms of adding another layer of meaning by means of its indirectness, also provides a contrast intended to keep the reader alert in the act of actualizing the literary work. Local irony, therefore, is common to both novels and plays; when it comes to plays, they are not written only to be read, but also to be performed on stage by live actors, for the enjoyment of a live audience, in a live interaction which depends on immediate response to the actions taking place on stage.

While the translation of plays may differ according to the intended mode of presentation, "for the page" vs. "for the stage," the fact remains that, in the act of writing, the playwright considered both channels of communication and wrote accordingly. 
One conclusion that could be drawn, therefore, is that the playwright chose to express the story, in general, and the irony, in particular, in such a manner as to entail its immediate interpretation, using simpler forms of communication at the expense of more complex ones, in order to meet the expectations of an audience who came to be entertained, to laugh in unison in the right places and to give a round of applause, none of which would be possible if the play were too difficult to be understood. On the other hand, in a novel such as Point Counter Point, in which, in the author's opinion, "however queer the picture is, it can never be half so odd as the original reality" (196), immediate understanding would defeat the purpose of the literary creation as envisaged by Aldous Huxley.

Finally, in order to answer the question of whether the literary genre dictates the use of particular translation strategies to the detriment of others, I return to the examples given above, and conclude that the same translation strategy, namely the second from Marta Mateo's (175-177) classification, ST irony becomes TT irony with "equivalent effect" translation, predominates in the translation of irony both in novels $(41.8 \%$ of the cases) and in plays (45.4\%). It was followed by strategy number (1), ST irony becomes TT irony with literal translation, in $33.3 \%$ of the cases in novels and $18.6 \%$ in plays. The only other strategy common both to the translation of irony in novels and plays was number (4): ST irony is enhanced in TT with some word / expression, in a percentage of 8.3 in the former category, and 9 in the latter. The differences between the two genres, in terms of translating irony, arise, on the one hand, when strategy number (10) - ST irony is explained in a TT footnote - is used only in novels (16.6\% of the cases); on the other hand, when strategies number (5) - ST ironic innuendo becomes more restricted and explicit in TT, number (9) - ST irony is replaced by a "synonym" in TT with no two possible interpretations, and number (11) - ST irony has literal translation with no irony in TT, are each used in $9 \%$ of the cases in the translation of irony only in plays. Whereas these last three negative strategies point to problems encountered by translators, and cannot be assumed to be common to the translation of irony in all plays, the explicitation of irony in translation by means of footnotes can be considered as a strategy commonly encountered in translated ironic novels.

\section{Cultural Factors - Constraints in Translating Irony?}

Ironic literary works are "anchored in time and space, [and] often require annotated versions or they run the risk of being dated too soon" (De Wilde 29); this is why an investigation of the socio-cultural and ideological context in which these texts were written is highly necessary before proceeding to their translation or, as is my case here, to the examination of the manner in which the different kinds of irony they contain were rendered in translation. 
Katharina Barbe considers (shared or diverging) background knowledge between author, translator and reader to be essential in detecting and understanding irony across languages and cultures, the main problem arising from the fact that "we cannot expect that all cultures have similar understandings and uses of irony." (qtd. in Ángeles Ruiz Moneva, "Searching for Some Relevance Answers" 217). She outlines the options translators have when facing irony, namely to (1) reproduce the irony, wherever the target language and culture allows it; (2) replace the source language "image" with an appropriate target language image; (3) amplify the source language irony in the target language by means of a potential irony marker by way of explicitation; or (4) maintain the source language idiosyncrasy in the target language. According to Barbe, the relationship between source and target texts and the methods by which the former is going to be transposed into the latter by means of translation depends to a great extent on the readers' awareness of the cultural issues referred to in the source text, on whether the irony is used for similar purposes, hence is intended to have a similar effect, or is hindered by institutional organizations (167).

In Lawrence Venuti's opinion, apart from politically governed institutions, which in some cases take it upon themselves to decide on the manner in which a translation ought to be made as well as whether or not to censor or, on the contrary, to promote various literary works, there are also other players involved in the publishing industry who are authorized to exercise their right to interfere with the translation process: publishers, editors and literary agents. Irony has been known to constitute one of the reasons why exceptional literary works have not been translated on ideological grounds. On the other hand, at the receiving end, there are the reviewers, the critics, whose shared opinions may determine the manner in which the translations are interpreted and received in the target culture. Whether the translator is compelled either to abide by the norms imposed by such players, or to deviate from them depends solely on extra-textual factors.

In "Translating Humphry Clinker's Verbal Humour" (2010), Marta Mateo follows the translation norms established by Gideon Toury in "The Nature and Role of Norms in Translation" (1995) in order to assess the translation of the verbal humour found in the epistolary novel The Expedition of Humphry Clinker written by Tobias Smollett (1771) into Spanish. She motivates her choice to abide by such norms based on the fact that they currently became the canon in literary translations "particularly for literatures from 'major' cultures" ("Translating Humphry Clinker" 182). According to Toury ("The Nature and Role of Norms" 53), the act of translating consists in performing a social role within a cultural environment in order to fulfil a function by conforming to a set of norms dictated by the "suitability of that kind of behaviour, and for manoeuvring between all the factors which may constrain it." These norms 
operate in either of the two directions, given the fact that they can also be applied in order to evaluate behaviour, not only to determine it. The conformity to norms has the advantage of creating a "regularity of behaviour" (Toury 55) within the same translation or with other translations of similar texts, thus ensuring consistency in the translation pattern. The two orientations available to the translator are the "adherence to source norms" (56), or the translation's adequacy to the source text, and theadherence to target norms, or the translation's acceptability in the target culture.

The first main direction where irony is concerned is represented by the ironologist Wayne C. Booth who, in A Rhetoric of Irony (1974), adopted a source-oriented, rhetorical stance on irony, regarded as stable and embedded solely into the textual construct; the second direction is represented by Linda Hutcheon'sIrony's Edge. The Theory and Politics of Irony (2005); in this book, she pleads for a more pragmatic, target-oriented approach, in which both author and reader share the attribution of ironic intention to the message communicated by the literary text. This latter, more dynamic perception of irony is considered to be "epistemologically superior for TS application" by July De Wilde (28), due to the fact that it can be more thoroughly examined within a descriptive, targetoriented, empirical research, which would yield more conclusive results. In this regard, the ironologist proposes a tripartite approach, entailing:

(1) a target-side investigation, related to the function which the target text is intended to fulfil, and consequently to the manner in which it produces effect on the translation product. This type of investigation could be employed in analysing the translation of Gulliver's Travels by Jonathan Swift as a novel and as an adaptation for children, thus removing all trace of irony in producing the structural change from a canonical literary work to a children's tale;

(2) a historical-descriptive analysis,referring to space-time specificities determined by the cultural, ideological, social, political, historical, geographical, etc. contexts in which the source text was written and by which it was potentially influenced; it is imperative for the translator to take them into account in his/her rendering of the source text into the target language environment. Satires are a good example in this regard as well, especially if there is a considerable time span between the moment of writing the source text and the moment of translation/reception in the target language, as satires most often find inspiration in particular social, political, etc. shortcomings and malfunctions;

(3) a translational interpretive oriented analysis, which was defined as the translator's vision on the source text, as it becomes apparent from the target text.By way of analogy, Marta Mateo's (2010) approach to translating verbal humour, a device which can at times be mistaken for or intermingled with verbal irony, is a practical one, undertaken from the perspective of the translator confronted with the literary ST, and motivated to make decisions and find the 
best translation strategies in order to fulfil what Vermeer and functionalist translation scholars call the translation skopos (Vermeer 2000).

According to Toury (58), the main groups of norms applicable to translation in general, and to the translation of irony in particular, are the preliminary and the operational norms. The former category is further divided into (1) translation policy, in other words, the factors that determine the choice of text-types (e.g.literary vs. non-literary)which are going to be conveyed to the target language and culture by means of translation and (2) directness of translation, i.e. thetolerance threshold involved in translating across languages and cultures, which inevitably entails shifts from the original text. The operational norms govern the decisions made throughout the process of translating and consequently determine the relationship between source text and target text (i.e. the factors that will remain constant in translation as well as those that will be subjected to shifts).

Lawrence Venuti was among the first scholars to comment upon Toury's method, which, in order to acquire significance, must heavily rely on cultural theory: "norms may be in the first instance linguistic or literary, but they will also include a diverse range of domestic values, beliefs, and social representations which carry ideological force in serving the interests of specific groups" (Venuti, The Scandals of Translation 29). He raises the issue of the translator's invisibility and discusses the dichotomy domestication vs. foreignization in order to address the issue of the extent to which translations assimilate the source text and culture in the target language and culture, as well as the extent to which translations can signal the differences specific to the source text. While domestication became the canon in translation in the AngloAmerican translation culture, in which the translator becomes invisible in the fluidity of the translation he produces, Venuti is strongly in favour of foreignization. A good translation, in his view, is one that emphasizes the foreignness of the source text instead of one in which the linguistic and cultural differences specific to the source text are completely levelled in the target language and culture. Thus, instead of the ethnocentric approach to literary translation, which dominates the Anglo-American world, and considerably limits the translator's options, turning him/her into a submissive executor, the ethnodeviant method acknowledges the translator's presence and becomes striking due to the fact that it attempts to preserve the differences which are specific to the foreign text. It is precisely this last approach that Marta Mateo favours in translating humour into Spanish with The Expedition of Humphry Clinker as a case in point (182).

In answer to the question of whether or not the culture in which a literary work was written dictates a more extensive use of irony over other similar indirect phenomena, Hatim (qtd.in Ruiz Moneva 222) emphasizes the preference of the English for irony: "for socio-cultural and linguistic reasons (...), English 
has developed a particular preference for understatement and the cryptic. Irony seems to be one of those aspects of verbal behaviour which benefit considerably from this kind of attitude to language use. In this context, the speaker can leave so much unsaid, yet express the attitude in question. But what is unsaid by no means leaves the utterance incomplete; on the contrary, the utterance will be 'pregnant' with meaning as a result. That is, English seems to allow some economy with the truth" (The Translator as Communicator 196). Whether one puts it down to truth-telling or simply to the fact that the English language dismisses what is superfluous, the fact is that English prefers economy of expression to more elaborate and descriptive forms of communication favoured by Romanian or French, for example, but it does not do so for the sake of clarity. It is perhaps for this reason that the English seem to display partiality for irony, which is, apart from everything else, an economic form of communication.

Another important aspect mentioned by Hatim refers to those translations which are conducted after a significant amount of time has passed since the original literary work was first published, a thing that entails inevitable diachronic changes: "Diachronic criteria are helpful in attempting to account for the way languages evolve in dealing with aspects of use such as irony. English prose of the nineteenth century, for example, shows unmistakable tendencies to flout Quantity and not Quality in relaying irony, a tendency which seems to have been on the wane in modern English" (Hatim qtd. in Ruiz Moneva 222). This statement suggests that in flouting Grice's maxim of quantity (make your contribution as informative as is required), English prose writers created irony by deliberately withholding informational content. This goes hand in hand with the preference of the Anglo-Americans for economy of expression, to which I have already referred above. It also confirms the definition of irony as something other than what is ostensibly said. It goes beyond the propositional content expressed by words and runs counter to the definition that (merely) confines irony within the boundaries of the exact opposite of what is communicated directly, and thus to flouting the maxim of quality (i e. making one's contribution true).

The problem raised by cultural factors in the translation of irony ultimately relies on the different modes of expression of universal meanings: "while almost all languages have at their disposal the potential ultimately to relay, say, a disparaging attitude [i.e. irony], what constitutes this in terms of rules of politeness, types of implicature, etc. (which are pragmatic concerns) and those of register appropriateness, level of formality, etc. (institutionalcommunicative concerns) can and does vary from one language to another" (Hatim qtd. in Ruiz Moneva 202). It results that, beyond the methods used in order to express ironic intent, which differ from one language to another, and from one culture to another, there is a deep structure (cf. Chomsky, Syntactic 
Structures) which is universal and shared by all languages, in opposition to the surface structure, which is different.

It stands to reason that the translator who operates with two languages at once ought to have, on the one hand, sound knowledge of the surface structure of linguistic expression particular to both languages and cultures, in order to be able to recognize them in the original literary work, as well as to render them accurately in translation and, on the other hand, a sense of the underlying ideas, beliefs, attitudes conveyed by such linguistic expressions, which are universal.

\section{Conclusions}

In this article I have attempted to demonstrate the complexity of translating irony in literary texts according to three main variables, perceived as contextual constraints, which also represent potential sources of risk, i.e. types of irony, literary genre and cultural factors. I have applied the only classification to date of strategies for translating irony (cf. Mateo, "The Translation of Irony") to the novels and plays that constitute the corpus of this study, a thing which has allowed me to attest to its operational character.

According to the findings, the most common strategies used by professional translators in order to render the main types of irony in the translation of both novels and plays are "equivalent effect" translation and literal translation. Verbal irony has been shown to raise most problems for translators due to the linguistic constructions of various degrees of ambiguity which are employed to achieve ironic effect, and which can be overlooked even by the translator him/herself. However, the majority of problems encountered in translating irony in literary texts are culture-specific. One way to solve such problems, which are more common to novels than to plays, is to explain the irony in translation by means of footnotes, avoiding thus more textually intrusive methods of translating irony. In general, the more intricate types and forms of irony are typical of novels, requiring a more complex process of interpretation, while the simpler, overt ironies that are meant to be perceived and interpreted at once, are prevalent in plays.

\section{Works Cited}

Abrams, M.H. A Glossary of Literary Terms. Boston: Thomson Wadsworth, 2005. Print. Anolli, Luigi, Rita Ciceri and Maria Giaele Infantino. "Irony as a Game of Implicitness: Acoustic Profiles.

of Ironic Communication.” Journal of Psycholinguistic Research. 29. 3(2000): 277-279. Print.

Barbe, Katharina. Irony in Context. Amsterdam/Philadelphia: John Benjamins, 1995. Print.

Booth, Wayne C. A Rhetoric of Irony. Chicago: The University of Chicago Press, 1974. Print. 
Chomsky, Noam. Syntactic Structures. Berlin, NW: Mouton de Gruyter, 2002. Print.

Colebrook, Claire. Irony (The New Critical Idiom). London/New York: Routledge, 2004. Print.

De Wilde, July. "The Analysis of Translated Literary Irony: Some Methodological Issues." Translating Irony. Eds. Katrien Lievois, Pierre Schoentjes. Linguistica Antverpiensia. New Series - Themes in Translation Studies. 9 (2010):25-44. Print.

Hatim, Basil. The Translator as Communicator. London /New York: Routledge, 1997. Print.

Hutcheon, Linda. Irony's Edge. The Theory and Politics of Irony. London/New York: Routledge, 2005. Print.

Huxley, Aldous. Brave New World. Toronto: Vintage Canada, 2007. Print.

Huxley, Aldous. Le meilleur des mondes. Trans. Jules Castier. Angers: Pocket, 1977. Print.

Huxley, Aldous. Minunata lume nouă. Trans. Suzana and Andrei Bantaş. Iaşi: Polirom, 2011. Print.

Huxley, Aldous. Point Counter Point. Leipzig: The Albatross, 1937. Print.

Kierkegaard, Søren. The Concept of Irony, with Constant References to Socrates. Trans. Lee M. Capel. Bloomington/London: Indiana University Press, 1971. Print.

Knox, Norman. "On the Classification of Ironies.” Modern Philology 70 (1972): 53-62. Print.

Knox, Norman. The Word Irony and its Context, 1500-1755.Durham, North Carolina: Duke University Press, 1961. Print.

Littman, David, Jacob L. Mey. "The Nature of Irony: Towards a Computational Model of Irony." Journal of Pragmatics 15 (1991): 131-151. Print.

Lodge, David. A David Lodge Trilogy: Changing Places, Small World, Nice Work. London: Penguin Books, 1993. Print.

Lodge, David. Ce mică-i lumea! O poveste din mediul universitar. Trans. George Volceanov. București: Univers, 1997. Print.

Lodge, David. Schimb de dame. Trans. Virgil Stanciu. Bucureşti: Editura Univers, 1999. Print.

Lodge, David. Small World, an Academic Romance. New York: Penguin Books, 1995. Print.

Lodge, David. Terapia. Trans. Radu Paraschivescu. Iaşi: Polirom, 2002. Print.

Lodge, David. Therapy. London: Penguin Books, 1996. Print.

Lodge, David. Un tout petit monde. Trans. Maurice and Yvonne Couturier. Paris: Éditions Rivages, 2014. Print.

Mateo, Marta. "The Translation of Irony." Meta: journal des traducteurs / Meta: Translators' Journal. 40.1(1995): 171-178. Print.

Mateo, Marta. “Translating Humphry Clinker's Verbal Humour.” Translation, Humour and Literature. Ed. Delia Chiaro. 171-195. London: Continuum, 2010. Print.

Muecke, D.C. Irony and the Ironic. New York: Methuen, 1982. Print.

Muecke, D.C. The Compass of Irony. New York: Methuen, 1969. Print.

Pădureleanu, Mircea. Aldous Huxley.Bucharest: Editura Ştiinţifică şi Enciclopedică, 1978. Print.

Ruiz Moneva, Ma Angeles. "Searching for Some Relevance Answers to the Problems Raised by the Translation of Irony." Revista Alicantina de Estudios Ingleses 14 
(2001): 213-24. Print.

Sperber, Dan and Deirdre Wilson. "Irony and the Use-Mention Distinction." Radical Pragmatics. Ed. P. Cole. 306-310. New York: Academic Press, 1981. Print.

Swift, Jonathan. Călătoriile lui Gulliver. Trans. Leon Leviţchi. Bucuresti: Editura pentru literatură, 1967.

Swift, Jonathan. Gulliver's Travels. London: Penguin Popular Classics, 1994. Print.

Toury, Gideon. "The Nature and Role of Norms in Translation." Descriptive Translation Studies and Beyond. Amsterdam/Philadelphia: John Benjamins, 1995. 53-69. Print.

Venuti, Lawrence. The Scandals of Translation: Towards an Ethics of Difference. London and New York: Routledge, 1998. Print.

Venuti, Lawrence (ed.). The Translator's Invisibility. Routledge, Taylor \& Francis eLibrary, 2004. Print.

Vermeer, Hans. "Skopos and commission in translational action."The Translation Studies Reader. Ed.

Lawrence Venuti.Trans. Andrew Chesterman.221-232. London/New York: Routledge, 2000. Print.

Wilde, Oscar. L'Importance d'être Constant. Trans. Charles Dantzig. Paris: Bernard Grasset, 2013. Print.

Wilde, Oscar. Teatru. Lady Windermere şi evantaiul ei, O femeie fără importanţă, Un sot ideal, Ce înseamnă să fii onest, Salomeea. Trans. Andrei Bantaş. Bucureşti: Editura Pentru Literatură Universală, 1967. Print.

Wilde, Oscar. The Importance of Being Earnest and Other Plays. London: Penguin Classics, 2000. Print. 